\title{
A dilatação do provisório nas \\ relações de amizade \\ em Glosa de Juan \\ José Saer
}

The dilation of the provisional in friendship relations in Glosa by Juan José Saer

Renata Cristina Pereira Raulino

Recebido em: 27 de setembro de 2020

Aceito em: 15 de outubro de 2020
Mestre em literatura hispano-americana pelo Programa de Pós-Graduação em Língua Espanhola e Literaturas Espanhola e Hispano-Americana da Faculdade de Filosofia, Letras e Ciências Humanas da Universidade de São Paulo. Doutoranda no mesmo Programa. Bolsista CAPES. Vinculada ao projeto de pesquisa "Espaços discursivos do eu e do outro. Memória, identidade, experiência e arquivo".

Contato: renata.raulino@usp.br Brasil 


\section{PALAVRAS-CHAVE:}

dilatação; amizade; comédia; Glosa; Juan José Saer

KEYWORDS: dilatation; Friendship; comedy; Glosa; Juan José Saer
Resumo: A amizade é o vínculo principal entre os personagens e fundamental para a construção narrativa de Glosa (1986), de Juan José Saer (1937-2005). Por essa razão, neste artigo, analisamos a amizade em Glosa como uma prática comunitária na qual os amigos celebram, passeiam e conversam - momentos fugazes, mas prazerosamente dilatados. Eles se encontram principalmente em dois espaços-tempos: uma festa e uma caminhada. $\bigcirc$ clima festivo não se materializa somente na interação entre os personagens nessas reuniões, mas também na voz narrativa, que se detém no deleite moroso das palavras. Argumentamos que Glosa é uma comédia especialmente porque narrador e personagens prolongam no tempo da escrita e da leitura instantes provisórios de amizade. Por outro lado, constatamos que tal comédia adia, mas não evita, a narração do destino trágico dos amigos, principalmente na prolepse do romance, relato do futuro dos personasens, relacionado aos efeitos da última ditadura militar argentina (1976-1983).

Abstract: Friendship is the main bond between the characters and it is fundamental to the construction of Glosa (1986), by Juan José Saer (1937-2005). We analyze friendship in Glosa as a community practice in which friends celebrate this connection, walking and talking - brief moments, but pleasantly dilated. This group reunites mainly in two space-times: a party and a walk. The festive atmosphere materializes in the interaction between the characters in these meetings and in the narrative voice, which pauses in the lengthy delight of the words. We conclude that Glosa is a comedy, especially because the narrator and characters prolong provisionally moments of friendship in the time of writing and reading. On the other hand, such comedy postpones, but does not prevent, the narration of the tragic fortune of the main characters, mainly in the novel's prolepsis, an account of the future of the characters, related to the effects of the last Argentine military dictatorship (1976-1983). 


\section{INTRODUÇÃO}

A amizade é o vínculo principal entre os personagens de Glosa (1986), romance do escritor argentino Juan José Saer (1937-2005). De acordo com Premat (2008), "Saer renueva el tópico literario argentino de la reunión de amigos y las trasnochadas discusiones intelectuales" (p. 180). Por sua vez, Beceyro (2017) afirma que "la amistad [na obra saeriana como um todo] no se teoriza, sino que se practica” (p. 33), pois “amigos se reúnen y hablan durante horas en asados, mesas de bar, acodados a la baranda frente a la laguna, caminando, etc.” (p. 33). No caso de Glosa, os amigos se reúnem principalmente em dois espaços-tempos: uma festa e uma caminhada. Portanto, a amizade é fundamental para a construção desta narrativa.

Em sua obra como um todo, Saer construiu um universo próprio de personagens que povoam a cidade argentina de Santa Fe - lugar nunca nomeado, mas reconhecível por sua geografia. Glosa se distribui em diferentes planos espaços-temporais e a linha central da história é uma conversa entre os amigos Ángel Leto e Matemático. Eles caminham vinte e uma quadras das ruas da cidade saeriana em um provável outubro de 1961. Essa caminhada define a divisão do romance: começa com "Las primeras siete cuadras", segue para "Las siete cuadras siguientes", até "Las últimas siete cuadras".

A narração do passeio é atravessada ao longo do romance pelo que os caminhantes pensam e conversam, especialmente sobre uma festa entre amigos: o aniversário de Washington Noriega, homem mais velho e elemento agregador do grupo ao qual tanto Leto quanto Matemático se vinculam. O interessante é que nenhum dos dois esteve na celebração, por isso ambos 
conversam sobre as versóes existentes do que ocorreu no dia. Matemático sabe sobre o que aconteceu no aniversário pela versão de um dos presentes, Botón. Ademais, outro convidado do aniversário - Carlos Tomatis - conta sua versão quando se encontra e conversa com Leto e Matemático no passeio. Portanto, o romance é um extenso comentário - um dos sentidos do título Glosa ${ }^{1}$ - de acontecimentos que Leto e Matemático não experimentaram em primeira mão, mas eles participam a posteriori ao comentar o aniversário durante a caminhada.

As versóes dos participantes da mesma celebração não se complementam nem se confirmam, mas se sobrepóem e se contradizem. Esta divergência de vozes aponta para outro sentido do título: variação musical que se executa com as mesmas notas. As versóes fragmentadas e incertas da festa são um fracasso no resgate do aniversário na sua inteireza e confiabilidade, mas produzem lembranças que multiplicam e prolongam as possibilidades e sentidos do relato de um mesmo acontecimento. Isso se dá porque a relação que se estabelece entre os personagens e entre narrador e personagens náo têm como base o consenso, o apaziguamento e a homogeneidade, mas sim o dissenso, o conflito e a heterogeneidade. Esse caráter conjectural da narração relaciona-se com a visão do escritor sobre a literatura. De acordo com o ensaio "El concepto de ficción", para Saer (1997), a ficção é uma antropologia especulativa sobre as possíveis maneiras de ser do homem, do

1 Esse sentido do título e outro que mencionamos a seguir foram extraídos da nota número 1 de Julio Premat, coordenador da edição crítico-genética de Glosa, publicada conjuntamente com El entenado em 2010. 
mundo e da sociedade. Por conseguinte, a especulação é o motor da sua criação dado que leva a narrativa saeriana para o terreno do inverificável e, portanto, do que pode ser de múltiplas maneiras.

A narrativa saeriana não avança desenvolvendo uma sucessão de acontecimentos dentro da estrutura progressiva de uma história porque, como afirma Oubiña (2005), é uma narrativa gerundial, uma prolongação infinita do instante por meio de um olhar que o esmiúça com demora. Esse crítico conclui que a descrição nos relatos saerianos não é instrumento de captura, mas uma operação que testemunha o que o olhar percebe e, logo em seguida, lhe escapa. Por sua vez, segundo Premat (2008): "para hablar de los textos de Saer, habría entonces que utilizar una forma verbal imperfectiva: no están escritos, sino siendo escritos, siempre por escribirse, siempre en movimiento” (p. 171).

No mesmo sentido, Dalmaroni e Merbilhaá (1999) associam a prosa saeiana ao discurso poético pela sua obsessão em detalhar a percepção dos personagens na narraçáo, na qual o narrador mostra um deleite moroso na materialidade das palavras. Portanto, o relato moroso póe na mínima velocidade a descriçáo minuciosa de objetos e atos cotidianos, o que exige dos leitores um tempo lento de leitura.

Levando em consideração o que dissemos, propomos ler as relaçóes de amizade em Glosa como uma prática comunitária, na qual se manifesta o prazer provisório e dilatado de celebrar, passear, conversar e debater entre amigos. Este clima celebratório não se encontra só na interação entre os personagens, mas também na voz narrativa, que se detém no deleite moroso 
das palavras. Para identificá-las assim, analisamos nas próximas páginas a narração das dinâmicas da rede de amigos nos espaços-tempos da festa e da caminhada que repercute essa mesma celebração. Argumentamos que Glosa é uma comédia especialmente porque narrador e personagens prolongam no tempo da escrita e da leitura instantes provisórios de amizade. Por outro lado, constatamos que tal comédia adia o que o narrador chama de "irremediable", a narração do devir trágico, especialmente na prolepse do romance. Essa é um relato do futuro dos personagens-amigos, relacionado aos efeitos da última ditadura militar argentina (1976-1983), tais como o exílio, a guerrilha, o desaparecimento e o suicídio.

O PRAZER COMUNITÁRIO DE COMER UM ASADO COM AMIGOS

Em Glosa, a amizade é uma relação que aparece antes de a narrativa começar porque a dedicatória encena o momento de entrega do texto como um presente e uma comédia:

A

Michel, Patrick, Pierre Gilles, que practican las tres ciencias verdaderas, la gramática, la homeopatía, la administración, el autor les dedica, por las sobremesas de los domingos, esta comedia:

but then time is your misfortune father said (Saer, 2013, p. 7, itálico do autor). 
O fragmento em itálico é uma citação de $O$ som e a fúria, romance de William Faulkner. Sobre esse trecho, López (2012) sugere que a comédia é dada para ser desfrutada em um agora ou antes que seja tarde porque o tempo transcorre infalivelmente e tanto o autor como seus amigos estáo conscientes da finitude da existência humana.

A crítica sustenta que a comédia é um tom que suspende provisoriamente o tempo cronológico. Ela aponta também duas distinçóes temporais quando vincula tempo e comédia: khronos e kairos. O primeiro é o tempo que passa; o segundo, um ponto no tempo carregado de um sentido derivado da sua relação com o fim.

Por um lado, López (2012) conclui que o autor convida os destinatários do texto (amigos-leitores) a conversar, a ler e a levar adiante açóes antes que o tempo passe no espaço em branco entre a primeira e a segunda parte da dedicatória. Por outro lado, a doação da comédia perfura a passagem do tempo e, portanto, constitui-se em um kairos, um ponto que suspende o khronos, uma fenda no devir inevitável. Assim, como o próprio narrador afirma: "la comedia [...] es [...] tardanza de lo irremediable, silencio bondadoso sobre la progresión brutal de lo neutro, ilusión pasajera y gentil que celebra el error en lugar de maldecir" (Saer, 2013, p. 198). Mais adiante no romance, descobrimos que o "irremediable", além de ser a inevitabilidade da finitude humana, é mais especificamente o futuro trágico-político de alguns membros desse grupo de amigos, especialmente os protagonistas Matemático e Leto, temporalidade que analisaremos com mais detimento na última parte deste artigo. 
Ainda na dedicatória, o autor dedica o romance a amigos ${ }^{2}$ com quem compartilhou "las sobremesas de los domingos". De acordo com Piglia (2010):

Los libros [de Saer] están escritos para los amigos. Dirigidos a los amigos, digamos mejor. La amistad es una red que sostiene el que escribe por fuera de cualquier circulación pública. De hecho, la amistad es una red que sostiene el modelo mismo de la lectura literaria: indecisa, intensa, fuera de todo control y de todo interés que no sea la literatura misma (p. XVIII).

Acrescentamos que, assim como um passeio e uma festa, a cena de leitura não tem outra finalidade a não ser a coexistência entre amigos em Glosa. "Las sobremesas de los domingos" antecipa o que será um dos argumentos centrais da narrativa, quando alude a laços de amizade associados à comida e às conversas despreocupadas: a tentativa de reconstrução do aniversário de Washington Noriega.

O que dissemos anteriormente dialoga com o que Jacques Derrida (1995) pensa sobre o dom em Dar el tiempo: la moneda falsa. A dedicatória antecipa que a narração que lhe segue apresentará uma temporalidade particular, o tempo que é dom para os amigos. Estes interrompem suas açóes regulares para se reunir na festa e na caminhada. De acordo com Derrida (1995), os instantes que fraturam a vida regular são dons sem retorno, pois não pertencem a alguém. O dom dá, requer e toma tempo.

Os amigos experimentam e levam em suas memórias instantes em comunidade dilatados pela narração, reunióes em que esbanjaram seu

2 De acordo com uma nota de Premat (2010), presente na ediçáo crítico-genética de Glosa e El Entenado, os destinatários são os amigos de Saer: Michel Launay, Patrick Lamonte e Pierre Gilles Gueguen. 
tempo entre si sem qualquer objetivo a náo ser estar e rir juntos. Sarlo (2016), assim como Beceyro (2017), salienta que boa parte dos personagens saerianos são amigos que compartilham conversas, comidas e espaços: "La conversación es, como las comidas y sus acciones preparatorias, la respuesta a una pregunta [...]: ¿qué se hace cuando [aparentemente] no se hace nada?" (p. 110).

Inclusive, as cenas fundamentais de convivência entre amigos em muitas narrativas saerianas são os asados, os churrascos. Para Gramuglio (2010), esses eventos são:

como ciertos motivos musicales en el interior de una partitura, $[\ldots]$ vuelven en estos pasajes la columna de humo ascendente, el rico jugo de la carne, los filamentos exangües de las pulpas masticadas, las texturas y los brillos de los alimentos, los chirridos de la cocción: imágenes cuyo denominador común, además, reside en la insistencia en la materialidad de los objetos y en el registro de la experiencia sensible de esa materialidad (p. 330).

A obra saeriana inicia no espaço-tempo de um asado. Por exemplo, "Algo se aproxima" - última narrativa de En la zona (1960), primeiro livro de Saer -, o narrador relata lentamente um churrasco organizado pelos amigos Barco e outro personagem sem nome. Os homens preparam o fogo e assam a carne, enquanto as mulheres montam e temperam a salada. As conversas narradas nessa confraternização, em que falam especialmente sobre assuntos literários, ocorrem entre esses homens. Raramente, as mulheres participam de forma ativa das conversas entre eles e parecem ser somente as parceiras amorosas dos dois amigos, formando um sutil quadrado amoroso. 
La Grande - último romance do autor, publicado inacabado e após a morte de Saer em 2005 - tem um tempo cronológico de sete dias. Nos cinco primeiros, o protagonista Gutiérrez organiza um asado e convida amigos, que reencontra depois de trinta anos de ter deixado a cidade. No sexto, um domingo, o narrador relata a festa. A carne e o vinho são abundantes e, em contraste, as saladas são mais frugais, o que leva um convidado a perceber no anfitriáo um desejo purista de conservar o asado das contaminaçóes urbanas, mantendo o seu caráter ritualístico. No sétimo, só há uma frase.

O purismo clássico de Gutiérrez afirma o pertencimento a uma tradiçấo viril do asado, tradição a qual o protagonista se agarra para tentar viver uma experiência perdida na sua juventude.

Por sua vez, em El río sin orillas: tratado imaginario, ensaio em que Saer reflete sobre características da sociedade argentina, enfatiza que essa comida é uma expressão da tradição nacional:

A pesar de su carácter rudimentario, casi salvaje, el asado es rito y promesa, y su esencia mística se pone en evidencia porque le da a los hombres que se reúnen para prepararlo y comerlo en compañía, la ilusión de una coincidencia profunda con el lugar en el que viven (Saer, 2012, p. 228).

Em outra passagem, também frisa:

un asado no es únicamente la carne que se come, sino también el lugar donde se la come, la ocasión, la ceremonia. Además de ser un rito de evocación del pasado, es [principalmente] una promesa de reencuentro y de comunión (Saer, 2012, p. 227). 
O asado, parte de um passado patriarcal argentino e expressão de sociabilidade nacional, é tradicionalmente masculino, assim como as relaçóes de amizade na narrativa saeriana. Por sua vez, as mulheres montam as saladas, elas só acompanham os homens, mas não preparam a carne ou protagonizam a narrativa saeriana, assim como a salada acompanha a carne.

Comer junto gera comunidade, comunhão, vínculo porque o prazer que a comida proporciona se desdobra no prazer de conversar. Em Glosa, a narração das lembranças do asado que proporcionou reencontros e comunhóes começa na evocação dos seus preparativos. No passeio em que a festa é lembrada, o personagem Matemático conta a Leto o que ouviu de Botón dias antes: Gato convidou Botón para o aniversário de Washington; o segundo se esqueceu de levar o seu violáo, mas levou garrafas de vinho branco; o aniversariante e os convidados chegavam ao local da celebração; enquanto um convidado instalava um barril de cerveja, outros preparavam a mesa em um quincho (cobertura de palha) ao lado de uma parrilla (churrasqueira) que assava peixes levados por outro convidado, etc.

Além disso, o asado é um dom, basta observar que a festa de aniversário é oferecida para Washington Noriega pelos seus amigos, único grupo representado na celebração. Matemático conta que o aniversariante não teve de contribuir com os gastos ou preparativos da festa. Esses foram divididos entre convidados, portanto o evento em si é uma demonstração de amizade ao aniversariante.

Depois que relata o contexto preliminar ao evento, Matemático conta o que Botón relatou do início de um absurdo debate sobre o tropeço de cavalos ao redor de uma parrilla (churrasqueira): 
Según parece, dice el Matemático, Noca le dijo a Basso que llegaba tarde porque uno de sus caballos habia tropezado y se habia quebrado una pata. Estaban [...] cinco o seis alrededor de Cohen, masticando cubitos de mortadela y tomando cerveza como aperitivo, y observando a Cohen que manipulaba brasas y leña, no sin hacer toda clase de muecas y lagrimear entre el calor y el humo del que los espectadores se mantenían a distancia confortable. Y cuando, según Botón, Basso había comentado la excusa de Noca, Cohen había interrumpido bruscamente su trabajo y, sin dejar de lagrimear y de hacer muecas dolorosas, se había plantado, perentorio, frente a Basso: ¿Desde cuándo los caballos tropiezan? (Saer, 2013, p. 46, itálicos do autor).

Em Glosa, há um desinteresse em representar personagens que conversam sobre algo edificante seriamente. No trecho acima, Matemático, a partir da versão do convidado-amigo Botón, relata um debate absurdo e, por isso, risível, tanto pelo conteúdo como pelo modo como os personagens atuam. Na obra saeriana, Sarlo (2016) ressalta que os personagens-amigos que conversam enquanto comem e bebem são inteligentes, mas eles não procuram debater ideias que pressuponham uma cultura livresca.

Segundo Bakhtin (1987), as conversas à mesa nas festas populares eliminam distâncias hierárquicas porque misturam o profano e o sagrado, o superior e o inferior, o espiritual e o material. Portanto, não há incompatibilidades nessas celebrações. Tal mescla de elementos antagônicos acontece em Glosa. A associaçáo entre o debate e o asado proporciona conversas livres do peso da seriedade. O prazeroso humor que o encontro entre amigos causa é especial pelo excessivo interesse que eles têm em conversar sobre assuntos banais, como cavalos, mosquitos ou uma simples festa de aniversário. Filosofar irresponsavelmente é delirante 
e, portanto, risível. Isso ocorre por causa da possibilidade de rir com e dos amigos nessas celebrações.

No presente prazerosamente dilatado desses encontros, os amigos estão obcecados pela vida e pelas experiências sensoriais que a festa lhes proporciona. Por exemplo, segundo a versão de Matemático-Botón, no fim da celebração:

[...] después de la noche que habían pasado, del alcohol y de la amanecida, de los toqueteos carnales y fugaces en los márgenes oscuros de la reunión, de la excitación de las discusiones, habían salido a la mañana gélida dichosos y reconciliados con el todo y deseaban, porque el olvido de sí actualizaba la esperanza, que esas ondas benévolas que los mecían se verificaran, incontrovertibles, en lo exterior (Saer, 2013, p. 139).

No trecho acima, os contatos e os sentidos nos corpos dos personagens são relatados em uma mescla, sem hierarquia de valor, apesar dos sentidos mais explorados no romance serem a visão e a audição. Segundo Corrado (2005), uma sonoridade recorrente na narrativa saeriana é a que produz as refeiçóes. O autor dá como exemplo o seguinte trecho de Glosa: "Debe haber habido una gritería general antes de pasar a la mesa; idas y venidas a la cocina, sillas que se arrastran; tintineos de platos, de cubiertos, vacilaciones" (Saer, 2013, p. 62).

O riso é o principal som de felicidade nas reunióes entre amigos:

Según Botón, de Noca, cuando se había armado la discusión sobre el caballo que tropezaba, Tomatis había dicho: Si el caballo iba hacia el boliche cuando tropezó, la culpa es del caballo; si volvía, la culpa es de Noca. Todos se reían (Saer, 2013, p. 57, itálico do autor). 
Acima, é Tomatis, personagem que também estará na caminhada contando sua versão do aniversário, que provoca o riso grupal e ridiculariza em uma frase o debate que movimenta as conversas na festa.

O riso também irrompe na caminhada em que Leto e Matemático conversam sobre a celebração. Por exemplo: "El Matemático se echa a reír. [...] Leto también se ríe, sacudiendo la cabeza. La risa, que expelen gargantas humanas y que chispea, al mismo tiempo, en ojos humanos, sale al aire tibio del exterior" (Saer, 2013, p. 41). Os caminhantes compartilham o ato de rir porque este é grupal e nunca solitário ao longo do romance.

O humor mostra a cumplicidade entre os amigos porque eles se comunicam também por meio dos seus corpos e conversas, na materialidade do riso dessas discórdias felizes que são essas reuniōes. Amigos rivais riem e desconfiam uns das opinióes dos outros para intercambiar a experiência de uma amizade que não elimina, mas estimula o conflito que mantém a liberdade de brincar e conversar, sem abrir máo de seus próprios pontos de vista. Por exemplo, na versāo Botón-Matemático, o aniversariante Washington Noriega atiça a expectativa dos presentes na festa com seu silêncio prolongado sobre o debate e, em seguida, rejeita o cavalo como um bom exemplo para a discussão, pois está excessivamente associado ao humano. Por isso, utiliza outro animal para refutar ridicularizando a opiniāo dos amigos, contando o seguinte: certa noite, o homenageado pelo asado estava lendo e percebeu a presença de três mosquitos. Esses agem de distintas maneiras, o que mostra o comportamento incerto, reflexáo recorrente também em outros livros de Saer, dos seres vivos. Sendo assim, essa história é um pretexto para uma 
reflexão sobre a imprevisibilidade dos animais e uma resposta inesperada para os participantes do debate.

$\mathrm{Na}$ caminhada, contando a sua versão da festa, Tomatis póe em xeque a intenção da resposta do aniversariante, argumentando que não se pode levá-lo totalmente a sério. Sobre isso, Balderston e Lucero (2010) ressaltam que a versão de Tomatis introduz no discurso de Washington a ambiguidade do humor porque é difícil saber quando o aniversariante fala na brincadeira ou seriamente, algo que Matemático enfatiza para Leto, um recém-chegado na cidade e no grupo de amigos no momento do passeio.

Ainda de acordo com os críticos acima, para o novo caminhante, a refutação do protagonista da festa pode ter sido um meio de ridicularizar os amigos que discutiam apaixonadamente sobre cavalos e a possibilidade do instinto animal permitir o tropeço. Sendo assim, concluem que o risco da zombaria atiça as dúvidas dos amigos-interlocutores, o que multiplica as possibilidades de sentido do discurso, assim como acontece com a tentativa de (re)construção da festa na caminhada. Por isso, os críticos comparam o aniversariante com o filósofo Sócrates dos diálogos platônicos ${ }^{3}$ porque ambos não ensinam aos seus interlocutores um conhecimento específico, mas sim um comportamento atento e desconfiado em relação ao discurso. No caso do romance em análise, Washington possui um tom ambíguo marcado

3 Na edição genética de Glosa/El entenado (2010), Julio Premat comenta na nota 33 como Saer se aproveita da estrutura de um diálogo platônico ( $O$ Banquete) para a trama central de Glosa e como o personagem Washington seria o seu Sócrates. De acordo com a introdução de uma recente edição de $O$ Banquete (2011), as perguntas de Sócrates despertam nos seus interlocutores o questionamento das suas convicçóes e, por conseguinte, o desejo de saber mais. 
pelo seu humor e leva a discussão central da festa a um plano dominado por dúvidas e desconfianças.

Em vista disso, o laço entre o aniversariantes e seus convidados é a que Piglia (2010) aponta como um dos principais tipos de amizade na obra saeriana como um todo: a relaçáo afetiva entre um velho e jovens, a qual alguns críticos da obra saeriana identificam como uma alusão a relação que o jovem Juan José Saer mantinha com o mais velho poeta Juan L. Ortiz 4 .

Portanto, como vimos até agora, as celebraçôes săo momentos em que a vida grupal se tornou leve e fugazmente mais intensa, pois envolvem as experiências sensoriais dos personagens e intensificam as suas relaçóes. Sobre a comida, Bakhtin (1987) alega:

Tristeza e comida são incompatíveis [...] Uma refeição [festiva] não poderia ser triste. O banquete celebra sempre a vitória, é uma propriedade característica da sua natureza. O triunfo do banquete é universal, é o triunfo da vida sobre a morte nesse aspecto, é o equivalente da concep̧̧âo e do renascimento (p. 247, itálicos do autor).

Em Glosa, os protagonistas evocam uma celebração que comemora os 65 anos de vida de Washington Noriega, mais um ano em que triunfa sobre a morte. Não é somente o prazer que os amigos buscam no aniversário, mas

4 Gramuglio (2010), por exemplo, sustenta que o escritor se inspirou em alguns de seus amigos intelectuais e artistas santafesinos para construir muitos dos seus personagens. Uma figura central de tal grupo foi Juan L. Ortiz (1896-1978), amigo, poeta e grande influência na literatura de Saer. Em "Juanele", prólogo dedicado às obras completas do poeta, Saer (1997) constrói uma filiação poética com ele e descreve como esse grupo de Santa Fe se reunia em encontros semelhantes à festa em homenagem a Washington Noriega, narrada em Glosa: reunióes na casa de Juanele, na casa de Saer ou outro amigo. Em tais encontros, os amigos conversavam durante horas ao redor de um "asado". 
também continuar a coexistir nesse grupo. A comunidade se constrói e se reconstrói em eventos de curto espaço de tempo.

Esses encontros não têm uma finalidade prática. De acordo com Agamben (2011), a festa na sociedade moderna não é descanso, não é fazer nada. Celebrar consiste em viver de outra maneira, divertindo-se, suspendendo, assim como o dom em Derrida (1995), a utilidade das atividades cotidianas. Sendo assim, esse evento náo se define pelo que os participantes fazem, mas sim pelo que eles transformam em inoperante:

Si comemos, no lo hacemos para asimilar la comida; si nos vestimos, no lo hacemos para cubrirnos o resguardarnos del frío; si nos mantenemos despiertos, no lo hacemos para trabajar; si caminamos, no es para ir a alguna parte; si hablamos, no es para comunicarnos informaciones; si intercambiamos objetos, no es para vender o comprar (Agamben, 2011, p. 162-163).

O excesso é outra característica que Agamben (2011) enfatiza sobre a festa como lugar de práticas inoperantes e que Derrida (1995) diz ser característica central da experiência doadora. A intensidade do desperdício em instantes prazerosos ocorre porque excede a vida cotidiana, regrada e calculada. O domtempo desses momentos tem de ser aproveitado ao máximo por ser provisório.

Em síntese, os convidados da celebração suspendem a finalidade de suas açóes nesses eventos: se divertem porque, entre outros motivos, desviam-se da normalidade da rotina diária. A festa é gratuita e, por isso, uma doação que transcorre tempo entre amigos. Segundo Derrida (1995), o dom da amizade é o gasto em pura perda, em um prazer autoafetivo. Em Glosa, os participantes comem para compartilhar e celebrar, e não para se saciar; 
permanecem acordados até a entrada da madrugada para que o aniversário dure. Ademais, o humor do narrador e dos personagens, no plano da narração e do enunciado, é uma prática que torna inoperante a seriedade do discurso filosófico, subvertendo-o, dando-lhe outra finalidade que não a busca de uma profunda verdade, mas a de rir e de discutir juntos.

Por conseguinte, Glosa é uma obra inoperosa ou inoperante, definida por Agamben (2017) da seguinte maneira:

A obra inoperosa, que resulta dessa suspensão da potência, expóe no ato a potência que a levou ao ser: se for uma poesia, exporá na poesia a potência da língua; se for uma pintura, exporá sobre a tela a potência do pintar (do olhar); se for uma ação, exporá no ato a potência do agir. Só nesse sentido pode-se afirmar que a inoperosidade é poesia da poesia, pintura da pintura, práxis da práxis. Ao tornar inoperosas as obras da língua, da política e da economia, ela mostra o que o corpo humano pode, abrindo-o para um novo uso possível (p. 117-118).

Assim, o artista desativa a linguagem de sua funçâo comunicativa/ informativa ao escrever poesia, paradigma da literatura para Agamben. Por meio dessa inoperância, há possibilidade para outro uso da língua, o poético/literário. Portanto, assim como os encontros e as conversas entre amigos, o narrador torna a narração inoperante porque explicita a sua potência de não comunicar algo definitivo, o que abriu possibilidades de contar desconfiadamente as diferentes versōes da festa de uma maneira obsessiva e prazerosa.

Leto e Matemático também transformam a caminhada em inoperante, e esse passeio sem destino favoreceu um imprevisível e temporário vínculo afetivo mais intenso entre os dois, além de viverem a celebração por meio das versôes. 
NO PASSEIO, UMA DISSONÂNCIA DE VOZES

Assim que Leto e Matemático se encontram por acaso, os dois conversam sobre a festa de Washington. Em comum, ambos têm a ausência: eles não compareceram ao evento, que ainda repercute nas conversas entre amigos. Leto, recém-chegado na zona saeriana e entre o grupo de amigos, não sabe porque não foi convidado e isso o perturba e o faz questionar o seu pertencimento ao grupo. Por sua vez, Matemático estava na Europa no dia da celebração, mas se ressente por não ter estado presente em um momento que parece ser mais valioso por não tê-lo vivido.

Conversar sobre o aniversário enquanto caminham é uma forma de não estarem completamente ausentes da celebração porque ambos participam da perpetuação desse evento nas suas memórias e na memória grupal dessa rede de amigos. Portanto, ao mesmo tempo que a exclusão produz um malestar nos dois ao se sentirem ameaçados por tal marginalização desse evento social, essa mesma sensação suscita a experiência narrativa da conversa sobre o aniversário.

O clima festivo contamina os caminhantes que conversam especialmente sobre a celebração, o que dá ao passeio um caráter celebratório. De acordo com Contreras (1991), o riso ocorre no passeio porque a narração detida da festa pelos caminhantes prolonga a experiência de um instante alegre no ato de lembrá-la conjuntamente.

A partilha das lembranças alheias da celebração possibilita a interferência nos debates, em retrospectiva, como no fragmento que segue: 
Y cuando, según Botón, Basso había comentado la excusa de Noca [...] se había plantado, perentorio, frente a Basso: ¿Desde cuándo los caballos tropiezan?, habia dicho.

— ¿Cómo? ¿No tropiezan? - dice Leto.

- Tropiezan. Tropiezan — dice, conciliador, el Matemático. Y después de una pausa dubitativa - : En fin, depende.

— ¿Depende de qué? - dice Leto.

—Depende de lo que se entienda por tropezar (Saer, p. 46, itálicos do autor).

Acima está um dos poucos trechos que o narrador dá voz aos caminhantes, uma vez que o discurso indireto livre domina a narração. Também é um dos poucos momentos que Leto questiona Matemático, contrariando-o diretamente e não somente em pensamento. Contreras (1991) observa que Matemático insiste em capturar a palavra mais insignificante, o tom mais sutil da discussão daquela noite e o modo evasivo de vozes familiares para poder aprovar, contestar, rebater cada uma dessas palavras. Essa interferência nos diálogos da celebração faz com que seu clima se prolongue para que algo dela pertença aos caminhantes.

O relato é possível e necessário por causa da exclusão do aniversário, porque não estar possibilita a reconstrução ficcional da memória. A ausência marginaliza fugaz e superficialmente Leto e Matemático do círculo de amigos e os faz desaparecer do relato da celebração. Em vista disso, a única forma de os protagonistas acessarem e participarem do que aconteceu e se discutiu no asado é por meio do intercâmbio de relatos fragmentários e duvidosos dos convidados da festa com os quais conversaram. Isto é, a dilatação da festa na caminhada também acontece pela proliferação de versôes sobre a mesma celebração. Essas se materializam especialmente na acentuação das 
divergências nos tons das vozes que relatam e conversam sobre a festa, as quais parecem expressar mais as diferenças que as semelhanças entre os amigos. Matemático diz de antemão para Leto que a versão da festa que ouviu de Botón necessita da sua correção precisa (matemática?) porque o último tende a dar a tudo que conta um tom fabuloso. Esse tom destoa do tom preciso que Matemático deseja marcar em sua narração da festa, mas não consegue porque constrói a versão de uma versão significativamente afetada pela amizade duradoura que o personagem tem com Washington e os outros convidados.

Por sua vez, na reunião entre Leto, Matemático e Tomatis em um trecho da caminhada, Ricci (informação pessoal) $)^{5}$ aponta que os gestos no encontro entre os três são importantes para entender os diferentes laços de amizade que os personagens têm entre si. Sobre o vínculo entre os dois protagonistas, o crítico diz:

En principio el aparente "olvido" de su acompañante por parte del Matemático al lanzarse, resuelto, hacia el otro lado de la calle para saludar a Tomatis. Allí se define un vínculo signado por la negatividad. El gesto involuntario del olvido del Matemático, vuelve a poner en escena el débil lazo de amistad que une a los dos protagonistas principales de la novela, la falta de confianza o de conocimiento mutuo (p. 17).

Por sua vez, sobre os gestos entre Matemático e Tomatis, afirma o seguinte:

El otro tipo de vínculo que se pone en escena en el momento del saludo de los tres personajes se reconoce en la efusividad, un tanto sobreactuada, que

5 Este trabalho de Ricci, no qual discute especialmente as relaçôes entre amizade e literatura na obra saeriana, é inédito e foi enviado pelo próprio autor por mensagem eletrônica. 
el Matemático y Tomatis representan "abrazándose, en la vereda, dándose palmadas en los hombros, en la espalda, en los brazos" (Glosa; 125). Esta imagen permite pensar, en primera instancia, en una amistad que funda sus cimientos en cierta sociabilidad pública, generacional y de grupo, pero que no terminará de alcanzar el tono íntimo y prescindente de esos gestos de las amistades que caracterizan a los personajes típicos de Saer. De todos modos la escena, visualmente impactante para el tercero que los observa, parece suficiente para hacer aflorar otra vez las dudas de Leto que, al aproximarse rezagado al encuentro de los otros dos también está representando, de algún modo, evidencia su reciente llegada al grupo de amigos (p. 17).

Tais diferenças entre os laços afetivos se materializa no conflito entre os três na conversa sobre a festa. $\mathrm{O}$ tom maledicente de Tomatis contamina o que conta sobre o aniversário, levando os outros caminhantes a "tomar con pinzas” sua versão. Além da versão de Botón parecer mais verossímil, ainda que fabulosa, a de Tomatis é uma "masa blanda y oscura que acaba de enchastrar la mañana con sus salpicaduras pegajogas" (Saer, 2013, p. 154). Ou seja, os protagonistas recusam o que esse amigo disse para que eles e a caminhada não se contaminem pelo seu humor negro.

Além das já mencionadas versôes dos convidados Botón e Tomatis, um terceiro convidado relata sua versão da festa na prolepse de Glosa, a qual conta o futuro trágico-político de alguns membros do grupo de amigos, muitos anos depois da caminhada entre os protagonistas. Os exilados Matemático e Pichón Garay passeiam pelas ruas de Paris e o último está convicto da presença de Matemático na festa.

O tipo de laço afetivo baseado na confrontação e na disputa na obra saeriana como um todo (Piglia, 2010) se pratica em Glosa nesses diferentes 
tons de contar uma festa. Como vimos, o tom fantasioso de Botón vai de encontro com o tom preciso de Matemático que, por sua vez, também confronta o tom maledicente de Tomatis e o tom convicto de Pichón. E todos esses modos de narrar, com exceção da versão que é relatada na prolepse, divergem na recepção de Leto, que poderia ser vista com um tom ingênuo porque ele não conhece nada ou pouco do grupo de amigos por ser um recém-chegado.

Por isso, Dalmaroni e Merbhilaá (1999) apontam um paradoxo na narrativa saeriana: os pontos de vista sob suspeita são a única forma de os personagens estarem no mundo e, acrescentamos, de se relacionarem. De maneira semelhante, Dema (2008) conclui que Glosa possui no seu centro temas fundamentais da narrativa saeriana: a dificuldade para estabelecer uma versão definitiva sobre um fato acontecido, o problema da fidelidade da memória e as limitaçóes da linguagem para transmitir fielmente uma experiência. Portanto, esse acesso ao mundo não está dado, mas se constrói ao longo da caminhada compartilhada entre os protagonistas. As versóes mostram uma história sempre mutante que se compóe de lembranças parasitárias e falsas "de un día de fin de invierno que no está inscripto en la experiencia [vivida] pero que sobresale, intenso, en la memoria” (Saer, 2013, p. 85). Sendo assim, o relato é também uma experiência que pode se transformar na memória dos personagens.

Em síntese, além de inoperantes e excessivas, as reunióes entre amigos possuem um sentido ludicamente incerto em suas conversas e nas distintas maneiras de lembrar desses encontros festivos. Assim como analisamos as 
relaçóes de amizade entre os personagens, em Dar (el) tiempo: la moneda falsa, Derrida (1995) faz um tipo semelhante de análise em uma narrativa de Baudelaire, "La moneda falsa". Em síntese, esse texto conta um passeio em que o narrador e um amigo caminham, conversam e fumam. Em certo momento, o segundo entregou uma moeda para um mendigo e, depois, confessou à voz narradora que havia entregado dinheiro falso.

No entanto, tal como em Glosa, Derrida (1995) destaca que o narrador desse texto enfatiza não saber se o amigo diz a verdade e conclui que "La moneda falsa" é uma construção narrativa enigmática, a qual mostra ao leitor o que permanecerá indecifrável. A narração está marcada de tal forma que, assim como o narrador, os leitores só têm a palavra do amigo, confiável ou não. Portanto, o texto é um dom na medida em que sempre se destinaria a alguém, mas é um dom sem crédito, sem valor. Sobre o título, Derrida (1995) explica que nunca se dá uma moeda verdadeira, uma moeda cujos efeitos podem ser calculados, uma moeda/narrativa com a qual se antecipa os acontecimentos que dela se esperam. A moeda falsa, paradigma do dom, é sempre surpreendente e misteriosa.

Em vista disso, as duas narrações, a que Derrida (1995) analisa e a que analisamos, são dons sem valor de verdade, assim como a amizade nos dois textos. Em Glosa, as relaçôes entre os personagens, entre os personagens e o narrador e entre o narrador e o leitor não pressupóem a confiança baseada no dizer ou conhecer a verdade e, portanto, não exigem as mesmas opiniốes ou interpretaçốes. Trata-se de seres unidos não pelas mesmas certezas ou pontos de vista, mas pelas desconfianças e divergências. Sendo assim, essas 
relaçóes entre os personagens criam uma narrativa que indaga e explicita seus limites e incapacidades de apreender o que se percebe e experimenta.

Além do humor evidenciar o caráter de gozo dos diálogos na festa e na caminhada, o próprio ato de conversar despretensiosamente causa satisfação: discordar por discordar é divertido. Portanto, as conversas entre amigos são estruturantes em Glosa, não por ser só o afeto privilegiado nas relações entre os personagens, mas também porque as vozes dissonantes dos amigos compóem o centro da trama: lembranças e experiências, alheias e próprias, duvidosas e singulares. Em concordância com Premat (2008), esse grupo é regido por "la incredulidad, una filiación de desconfianza, un código común de negatividad: ése sería el linaje intelectual tan argentino después de todo, que Saer crea en sus ficciones" (p. 183).

Como se viu, essas tentativas de captar demoradamente eventos provisórios por intermédio da captação demorada de certos pontos de vista divergentes são um fracasso no sentido de não alcançar uma narração completa ou harmoniosa de tais instantes. Quanto mais o narrador e se aproxima do que relata, maior a confusão. A voz narradora sente, simultaneamente, angústia por não conseguir dar conta do que narra e gozo no próprio ato de narrar, que nunca cessa de buscar diferentes maneiras de contar minuciosamente a percepção dos personagens, uma vez que o narrador é, segundo Arce (2013), como uma caixa de ressonância dos pontos de vista dos protagonistas.

A caminhada dos personagens principais e o que conversam é fundamental para gerar uma partilha parcial de percepçóes. $\mathrm{O}$ trecho abaixo está em uma das últimas páginas das primeiras sete quadras - primeira parte de Glosa 
- e mostra que a conversa de Leto e Matemático, reconstruído com versóes alheias, suscita um laço provisório, uma proximidade provisória entre os caminhantes:

Desde que empezaron a recorrer juntos la calle recta [...], un nuevo lazo, impalpable, los emparenta: los recuerdos falsos de un lugar que nunca han visitado, de hechos que nunca presenciaron y de personas que nunca conocieron, de un día de fin de invierno que no está inscripto en la experiencia pero que sobresale, intenso, en la memoria [...] (Saer, 2013, p. 85).

A caminhada é um tempo-espaço que conflui e aproxima amigos no seu particular processo de construir lembranças alheias e próprias de um evento passado que começa a fazer parte da memória de cada um dos membros de maneira única, mas bastante imprecisa. Agamben (2009) postula que os amigos não con-dividem algo, mas sim a própria experiência da amizade. Essa se materializa no passeio que evoca lembranças alheias de um asado, no qual se dão debates regados a carne e álcool, e isso possibilita que os ausentes também tenham palavra nessas conversas, dando maior intensidade ao laço de amizade entre os dois. Tal con-divisão não se restringe somente ao relato do evento e ao passeio em si, mas a experiências estéticas compartilhadas, como a escuta de uma música, a leitura de um poema ou a observação repentina de um quadro. Estar ou não envolvido em tais experiências é estar ou não con-dividindo a experiência da amizade.

A experiência narrativa compartilhada da festa mostra que Matemático reconhece em Leto um membro da rede de amigos. Por sua vez, apesar da insegurança em relação ao seu lugar nessa rede, o segundo reconhece o primeiro 
como um membro do círculo ao lhe conferir o poder da narração. Apesar de o laço dos dois ser frágil, ambos não questionam a existência do outro no círculo de amigos e há o estabelecimento de uma promessa de amizade mais sólida entre eles, a qual não se cumpre. Por esse motivo, a experiência narrativa e a consequente amizade acidental de Leto e Matemático garantem, provisoriamente, a sua coexistência como membros do grupo de amigos.

Concordamos com Ricci (informação pessoal) quando afirma que a amizade entre os protagonistas não é duradoura como outras desta narrativa - por exemplo, a amizade entre Matemático e Pichón Garay ou entre Leto e Tomatis, que voltam à cena na prolepse - ou de outras narrativas de Saer. A amizade entre os caminhantes está no tempo do passeio. Este dura quarenta e cinco minutos, mas se estende no tempo da leitura: a amizade entre eles vai coexistindo nessa dilatação. Portanto, além das rememorações que se desenvolvem e compartilham entre si, a caminhada em si mesma é fundamental na construção e na explicitação da relação de amizade entre Matemático e Leto, pois a experiência narrativa na conversa se entrelaça com a experiência da caminhada a ponto de uma não prosseguir sem a outra: a narração do aniversário segue somente quando os personagens estão caminhando e se interrompe quando atravessam a rua.

A dinâmica da amizade entre Leto e Matemático é frágil e incipiente: o decorrer da caminhada dissolve uma amizade que náo teve tempo para se solidificar, mas o narrador faz o leitor se deter nesses encontros efêmeros que se transformam em duradouros pela narração e leitura. Narrador e personagens prolongam a experiência do instante no relato da festa. 


\section{COMÉDIA, DILATAÇĀO PROVISÓRIA DO FIM TRÁGICO}

As correçôes bruscas e desdenhosas do narrador em torno do que os personagens pensam e das especulaçóes sobre suas mínimas açóes levam Balderston e Lucero (2010) a concluir que o humor do narrador incita o riso no leitor por ser uma paródia da onisciência narrativa, já que esse narrador se preocupa exageradamente em dar conta de detalhes, de erros e de incongruências por meio de um olhar tortuoso e brincalhão.

Sendo assim, os críticos anteriores veem o romance como uma brincadeira, pois concluem que o tom comicamente dubitativo do narrador - assim como as glosas da festa e os debates entre os personagens-amigos - não pretende esclarecer, mas desconcertar o leitor com inesgotáveis reformulaçôes e questionamentos, mostrando o lado risível das preocupaçóes do narrador e dos personagens. Em vista disso, concluímos que a voz narrativa estabelece com o leitor uma cumplicidade semelhante à das relaçôes de amizade entre os personagens.

Assim como a amizade entre Leto e Matemático, o romance é possível no limite restrito da caminhada, entre a primeira e a última página/quadra, apesar das incertezas, da proliferação de um passado inapreensível e de um futuro nefasto para os personagens, devir relacionado aos efeitos trágicos e inescapáveis da última ditadura militar argentina. De acordo com Berg (1999): "La glosa como guerra de versiones, como expansión proliferante del chisme, del rumor o del comentario maledicente construye el único suspenso posible que precede al otro tiempo, el tiempo que ingresa en tanto violencia atroz de la historia” (p. 17). 
O instante de prazer - que é também o tempo de leitura - é efêmero, mas efetivo. Por isso Contreras (1991) argumenta que a demora na narração desses encontros de curto tempo cronológico é uma forma de resistir à consciência da dor da finitude humana, porque o prazer que as reunióes proporcionam para os personagens-amigos se reflete na narração e leitura, e faz com que personagens, narrador e leitores se esqueçam provisoriamente de que esses encontros, assim como sua narrativa e leitura, terão um triste fim.

A crítica anterior analisa o poema que é epígrafe do romance - "En uno que se moría/mi propia muerte no vi/pero en fiebre y geometría/se me fue pasando el día/ y ahora me velan a mí” (Saer, 2013, p. 9) -, e ela observa que os versos recusam o tom grave que pressuporia a profundidade da sua mensagem (a experiência de não ser contemporâneo da própria morte), pois a sua sonoridade é leve, lúdica. Ela supóe que uma música cômica desvia a atenção do leitor do conteúdo grave da mensagem, distração que antecipa o que acontecerá no romance que lhe segue.

Como mostramos na parte anterior artigo, Leto e Matemático se distraem provisoriamente dos seus sentimentos de exclusão no passeio que prolonga a festa porque emergem do pântano de suas consciências para conversar sobre a celebração. Isto é, a tristeza que carregam dentro de si não cessa, mas é aliviada momentaneamente. Além do mais, muitas vezes o humor resulta de uma tensão provocada pelo desconcerto entre um tom, um comportamento e um tema. $\mathrm{O}$ poema e o romance sáo escritos de maneira semelhante a como escreve Brás Cubas, "com a pena da galhofa e a tinta da melancolia”. 
Contreras (1991) frisa que tal inadequação se evidencia mais ainda na cena de leitura desses mesmos versos na caminhada: Tomatis, autor do poema na narraçáo, muda o tom de sua voz e lê o poema com uma irônica solenidade; Matemático compreende e se extasia; Leto não escuta; Tomatis volta a lê-lo menos atento ao poema que à reação de Leto; Matemático controla e reprova com seu olhar a desatençáo desse amigo; Leto, pressionado pela dupla vigilância, outra vez não escuta. A crítica presume que os leitores esquecem o sentido profundo dos versos e riem porque se distraem pela engraçada tensão da cena, salientando que a demora nesses momentos não provoca no leitor o riso que tem a força de uma gargalhada desdenhosa ou cínica porque o riso em Glosa náo é um ataque contra a morte, mas possui a astúcia do esquecimento, uma forma de resistir provisoriamente à tristeza.

Essas e outras análises do romance levam a crítica acima a concluir que, assim como os personagens-amigos, narrador e leitores querem esquecer a dor do fim. Por isso, desfazem-se provisoriamente dos relatos do futuro que irromperão no romance transformando negativamente, ou às vezes destruindo a vida de muitos dos membros do grupo de amigos ${ }^{6}$.

O prolongamento da festa em evocações na caminhada que se dilata prazerosamente adia provisória e conscientemente o relato da separação

6 De acordo com Bracamonte (2007), os personagens de Glosa encarnam 4 estados políticos-civis importantes da última ditadura militar argentina na prolepse do romance: os exilados do país por motivos pessoais e depois ideológico-culturais (Pichón Garay) ou diretamente ideológicos (Matemático); os isolados culturalmente na Argentina em contexto ditatorial (Tomatis); os desaparecidos (Gato Garay e Elisa); os guerrilheiros e suicidas (Leto). Salientamos que Glosa é publicada três anos depois, 1986, do fim da última ditadura militar argentina, em 1983, e a prolepse do romance está cronologicamente localizada nos anos 70. 
e o fim do grupo de amigos por razóes especialmente político-históricas. Contreras (1991) argumenta que a alegria de estar juntos fornece-lhes uma espécie de anestesia para a finitude humana porque o riso tem o poder de exorcizar o medo da morte, mas só durante o tempo curto dilatado que dura uma gargalhada porque contra os vislumbres de tristezas futuras para os personagens, prevalece no tempo de leitura do romance a demora nos instantes efêmeros desses encontros.

A morte e os outros efeitos do terrorismo de estado ditatorial são catástrofes anunciadas e inevitáveis, mas os personagens e o leitor desconhecem o dia e o modo como acontece até que o romance esteja avançado. $\mathrm{O}$ leitor sabe que os personagens se dirigem para um fim, mas quando o fim não é conhecido na primeira leitura, podemos esperar que não esteja próximo, até o momento em que o catastrófico irrompe. Em concordância com Kohan (2011), a narração da prolepse se insere em um todo narrativo em que o político-histórico irrompe sintética e intensamente. Isto é, os efeitos da ditadura são escritos de forma precisa e condensada para interromper o prazer estético de uma narrativa predominantemente morosa que narra momentos provisoriamente felizes porque também irrompe dessa maneira na história dos personagens que sofrem as suas consequências.

Talvez seja por isso que, além do prolongamento do presente prazeroso, o narrador detalha os futuros mais trágicos dos personagens - a depressão e isolamento de Tomatis e a guerrilha e suicídio de Leto - predominantemente no futuro do indicativo, tempo que coloca, segundo Pereira Jr. (2006), o que acontecerá com os personagens "fora" do presente da narrativa. 
Ademais, os saltos para o futuro da caminhada para contar o destino trágico dos personagens não são o fim do romance. Depois que a voz narrativa deixa o leitor consciente de que a dispersão da rede de amigos virá e de que Leto se suicidará, há uma volta para o presente e para um Leto jovem, vivo e ignorante do que lhe espera.

O romance-comédia termina bem, mas provisoriamente porque, como diz Saer, em conversa com Piglia (1995):

Yo llamé a Glosa una comedia porque la comedia está antes del fin. El fin está elidido en las comedias. Terminan bien, pero provisoriamente.

Se puede tener esa visión del mundo: que está provisoriamente bien. Y cuando me refiero al mundo no solamente me refiero a la sociedad, a la vida de cada individuo, sino también al universo. En Lo imborrable, el narrador dice, en un determinado momento, "la tierra está girando, pero provisoriamente". Cuando tomamos conciencia de que todo es provisorio nos damos cuenta de que, al mismo tiempo, es una situación altamente cómica. Si escuchamos el discurso del presidente de la República a propósito de su reelección y sabemos que vivimos en un universo provisorio, esas pretensiones naufragan inmediatamente en el ridículo. Pienso que el humor cumple esa función (1995, p. 83).

Portanto, além do esquecimento provisório da consciência de que tudo tem um fim nos encontros desses personagens que se reflete na narração e no tempo de leitura, a consciência de que tudo é provisório dá um novo sentido para o romance depois que o leitor tem acesso a esses futuros: os personagens-amigos, juntamente com narrador e leitores, devem aproveitar o presente enquanto ele não se esvai. Carpe diem. $\mathrm{O}$ dom do instante vivido e compartilhado entre amigos é uma dissonância, uma inadequação feliz a esse tempo devastador do político-histórico. 
A narrativa e os personagens do romance em análise são como o viajantenarrador Marco Polo de Cidades invisiveis, de Ítalo Calvino. O objetivo de suas viagens é o seguinte:

- Sim, o império está doente e, o que é pior, procura habituar-se às suas doenças. O propósito das minhas exploraçóes é o seguinte: perscrutando os vestígios de felicidade que ainda se entreveem, posso medir o grau de penúria. Para descobrir quanta escuridão existe em torno, é preciso concentrar o olhar nas luzes fracas e distantes (2017, p. 70).

Concluímos que a centralidade e a dilatação narrativas nos instantes felizes da comunidade de amigos de Glosa jogam para um segundo plano a força política que irá pressionar alguns personagens na prolepse do romance. Ao invés da narrativa representar um lamento pelos catastróficos efeitos de uma violenta ditadura militar, mostra a alegria dos personagens-amigos em estar juntos.

\section{REFERÊNCIAS BIBLIOGRÁFICAS}

Agamben, Giorgio. "O amigo". In: O que é o contemporâneo? e outros ensaios. Chapecó, SC: Argos, 2009, p. 79-92.

Agamben, Giorgio. "Un hambre de buey”. In: Desnudez. Buenos Aires: Adriana Hidalgo, 2011, 153-165.

Agamben, Giorgio. O uso dos corpos. São Paulo: Boitempo, 2017.

Arce, Rafael. "La pasión de lo real". In: CONTRERAS, Sandra (ed.) Realismos: cuestiones críticas. Rosario: Centro de estudios de Literatura Argentina y Humanidades; Artes Ediciones, 2013, p. 29-43.

Bakhtin, Mikhail. A cultura popular na Idade Média e no Renascimento: o contexto de François Rabelais. São Paulo: Hucitec, 1987. 
Balderston, Daniel; Lucero, Nicolás. "Diálogos, risas y tropiezos en Glosa". In: SAER, Juan José. Glosa/El entenado. Edición crítica. Julio Premat (coord.) Poitiers, Córdoba: CRLA, Alción, 2010, 683-696.

Beceyro, Raúl. "Sobre Juan José Saer: 10 observaciones sin importancia”. In: Cuadernos de cine documental, n. 11, Santa Fe: 2017, 26-33. Disponível em: <https://bibliotecavirtual.unl.edu.ar/publicaciones/index.php/ CuadernosDeCine/article/view/7041>. Acesso em: 11 out. 2020.

Berg, Edgardo. “'Hojas de ruta' (La ciudad como escenario en Glosa, de Juan José Saer)”. In: CELEHIS: n. 11, Mar del Plata: 1999, 11-22. Disponível em: <https://fh.mdp.edu.ar/revistas/index.php/celehis/article/download/409/1011>. Acesso em: 11 out. 2020.

Bracamonte, Jorge. Los códigos de la transgresión. Lengua literaria, lengua política y escritura contemporánea en la narrativa Argentina. Córdoba: Jorge Sarmiento Universitas libros/Facultad de Filosofía y Humanidades (UNC), 2007.

Calvino, Ítalo. Cidades invisiveis. São Paulo: Companhia das Letras, 2017.

Contreras, Sandra. "Glosa, un atisbo de fiesta". In: Paradoxa, n. 6, Rosario: 1991, 43-52. Disponível em: <http://www.lectorcomun.com/archivos/ files/5ContrerasParadoxa6.pdf>. Acesso em 08 jan. 2014.

Corrado, Omar. "Sonido, tiempo, forma: una escucha musical de los textos de Juan José Saer”. In: Revista del ISM, v. 1, n. 5, Santa Fe: nov. 2005, 24-49. Disponível em: <https://bibliotecavirtual.unl.edu.ar/ojs/index.php/ISM/article/ view/512>. Acesso em: 22 jul. 2020.

Dalmaroni, Miguel; Merbilhaá, Margarita. “'Un azar convertido en don’. Juan José Saer y el relato de la percepción”. In: JITRIK, Noé (dir.) Historia crítica de la literatura argentina, v.11. Buenos Aires: Emecé, 1999, 321-343.

Dema, Pablo. "El relato literario y la memoria colectiva". Borradores, v. VIIIIX, Córdoba: 2008, 1-9. Disponível em <http://www.unrc.edu.ar/publicar/ 
borradores/Vol8-9/pdf/El\%20relato\%20literario\%20y\%20la\%20memoria\%20 colectiva.pdf $>$. Acesso em: 11 out. 2020.

Derrida, Jacques. Dar (el) tiempo. La moneda falsa. Barcelona: Paidós Ibérica, 1995.

Gramuglio, María Teresa. "El lugar de Saer". In: Crítica cultural, n.. 2, v. 5., Santa Catarina: 2010, 325-347. Disponível em: <http://www.portaldeperiodicos. unisul.br/index.php/Critica_Cultural/article/view/695/650>. Acesso em: 22 jul. 2014.

Kohan, Martín. “Glosa, novela política”. In: Ricci, Paulo (ed.). Zona de prólogos. Buenos Aires: Seix Barral, 2011, 147-160.

López, Silvana. “Temporalidad, fantasma y narración en 'Glosa' de Juan José Saer”. In: Chasqui, n. 2, v. 41, Arizona: nov. 2012, 164-182. Disponível em: < http:// www.jstor.org/stable/43589465>. Acesso em: 22 jul. 2020.

Assis, Machado de. "Memórias póstumas de Brás Cubas". In: Obra completa, vol. I. Rio de Janeiro: Nova Aguilar, 1994.

Oubiña, David. "La extenuación". In: Lecturas de Juan José Saer: una celebración de "la zona", 2005. Anais eletrônicos ... Buenos Aires: Universidad de San Andrés, MALBA,2005, 13-18. Disponível em: <http://repositorio.udesa.edu.ar/jspui/ bitstream/10908/445/1/\%5bP\%5d\%5bW\%5d\%20DT38-Lecturas\%20de\%20 Juan\%20Jos\%C3\%A9\%20Saer.pdf>. Acesso em: 22 jul. 2020.

Pereira Jr., Antônio D. Glosas e silêncio em Juan José Saer. 124f. Dissertação de mestrado. IEL/Unicamp, São Paulo: 2006. Disponível em <http://www. bibliotecadigital.unicamp.br/document/?code=vtls000384518> Acesso em: 11 out. 2020.

Piglia, Ricardo. "La amistad en Saer". In: SAER, Juan José. Glosa/El entenado. Edición crítica. Julio Premat (coord.) Poitiers, Córdoba: CRLA, Alción, 2010, p. XVII-XX.

Platão. O banquete. $3^{\text {a }}$ ed. Belém: ed. ufpa, 2011. 
Premat, Julio. "Saer, un escritor del lugar". In: Héroes sin atributos: Figuras de autor en la literatura argentina. Buenos Aires: Fondo de Cultura Económica, 2008, p. 167-202.

Ricci, Paulo. La condición inmortal. São Paulo, 6 de ago. 2015. 1 mensagem eletrônica.

Saer, Juan José. El concepto de ficción. Buenos Aires: Ariel, 1997.

Saer, Juan José. Cuentos completos (1957-2000). Buenos Aires: Seix Barral, 2004. E-book.

Saer, Juan José. La grande. Buenos Aires: Seix Barral, 2005.

Saer, Juan José. Glosa/El entenado. Edición crítica. Julio Premat (coord.). Poitiers, Córdoba: CRLA, Alción, 2010.

Saer, Juan José. El río sin orillas. Buenos Aires: Seix Barral, 2012 [1991]. E-book.

Saer, Juan José. Glosa. 5a ed. Buenos Aires: Seix Barral, 2013 [1986].

Saer, Juan José; Piglia, Ricardo. Diálogo. Santa Fe: Centro de Publicaciones Universidad Nacional del Litoral, 1995.

Sarlo, Beatriz. Zona Saer. Santiago de Chile: Ediciones Universidad Diego Portales, 2016. 